\title{
PENERAPAN MODEL PEMBELAJARAN COURSE REVIEW HORAY \\ UNTUK MENINGKATKAN MINAT BELAJAR SISWA PADA PEMBELAJARAN BAHASA INDONESIA KELAS VI SDS METHODIST-2 MEDAN
}

oleh

\author{
Ceing Suwarni (ceingsuwarni@gmail.com)
}

\begin{abstract}
ABSTRAK-Penelitian ini bertujuan untuk meningkatkan minat belajar siswa pada pembelajaran Bahasa Indonesia Kelas VI SDS Methodist-2 Medan Tahun Pembelajaran 2019/2020. Penelitian tindakan kelas ini dilaksanakan dalam 2 siklus, setiap siklus terdiri dari perencanaan, pelaksanaan tindakan, pengamatan, dan refleksi. Subjek penelitian ini adalah siswa kelas VI sebanyak 34 orang, data dikumpulkan melalui observasi, test, dan foto dokumentasi. Hasil persentase kinerja guru pada siklus I yaitu sebesar $65 \%$ dengan kategori cukup. Sedangkan untuk minat belajar siswa saat mengerjakan LKS sebesar 65\%, minat siswa pada saat pembahasan soal sebesar $74,4 \%$, minat siswa pada saat pembahasan materi pelajaran sebesar $80 \%$, minat siswa pada saat evaluasi sebesar $80,4 \%$. Selanjutnya hasil persentase kinerja guru pada siklus II adalah sebesar 85\% dengan kategori sangat baik. Dan persentase siswa aktif dalam belajar sebesar $88 \%$ dengan kategori sangat baik. Untuk minta minat siswa saat mengerjakan LKS sebesar $88,4 \%$, minat siswa pada saat pembahasan soal sebesar $86,8 \%$, minat siswa pada saat pembahasan materi pelajaran sebesar $88 \%$, minat siswa pada saat evaluasi sebesar $90,4 \%$. Untuk evaluasi belajar tersebut nilai rata-rata 86.56 maka dapat disimpulkan bahwa melalui model pembelajaran course review horay dapat dijadikan sebagai upaya menumbuhkan minat belajar siswa pada pelajaran Bahasa Indonesia kelas VI SDS Methodist-2 Medan TP. 2019/2020
\end{abstract}

Kata Kunci: Course Review Horay, Minat Belajar, Bahasa Indonesia 


\section{A. PENDAhULUAN}

Guru sebagai salah satu sumber belajar berkewajiban menyediakan lingkungan belajar yang kreatif bagi kegiatan belajar belajar anak didik di kelas. Menurut UU No. 20 tahun 2003 pendidikan merupakan usaha sadar dan terencana untuk mewujudkan suasana belajar dan proses pembelajaran agar peserta didik secara aktif mengembangkan potensi dirinya. Agar memiliki kekuatan keagamaan, pengendalian diri, kepribadian, kecerdasan serta keterampilan.

Dari sekian banyak komponen pendidikan, guru merupakan faktor yang sangat penting dalam usaha peningkatan pendidikan. Dalam mengembangkan metode pembelajaran seorang guru harus dapat menyesuaikan antara metode yang dipilihnya dengan kondisi siswa, materi pelajaran, dan sarana yang ada. Salah satu kemampuan yang harus dipilih oleh seorang guru dalam meningkatkan kompetensi profesinya ialah kemampuan mengembangkan metode pembelajaran.

Sebagai upaya menumbuhkan minat belajar siswa pada pembelajaran Pendidikan Bahasa Indonesia, guru perlu mengintergrasikan faktor-faktor berikut:

1. Menciptakan kondisi terbaik untuk belajar;

2. Bentuk presentasi yang melibatkan sebanyak mungkin indera dan sekaligus membuat relaks, menyenangkan, bervariasi, cepat dan menggairahkan;

3. Berpikir kreatif, dan kritis untuk membantu penguasaan materi;

4. Rangsangan dalam mengakses materi pelajaran dengan permainan, serta kesempatan untuk praktek; penjalin interaksi timbal balik;

5. Peninjauan ulang dengan evaluasi secara teratur dengan merayakan keberhasil setiap tahap.

\section{Kajian Pustaka}

\section{Pengertian Minat Belajar}

Untuk mencapai prestasi yang baik di samping kecerdasan juga minat, sebab tanpa adanya minat segala kegiatan akan dilakukan kurang efektif dan efesien. Dalam percakapan sehari-hari pengertian perhatian dikacaukan dengan minat dalam pelaksanaan perhatian seolaholah kita menonjolkan fungsi pikiran, sedangkan dalam minat seolah-olah menonjolkan fungsi rasa, tetapi kenyataanya apa yang menarik minat menyebabkan pula kita kita berperhatian, dan apa yang menyebabkan perhatian kita tertarik minat pun menyertai kita." (Dakir, 2004)

Menurut Dyimyati Mahmud (2001) menyatakan bahwa minat adalah sebagai sebab yaitu kekuatan pendorong yang memaksa seseorang menaruh perhatian pada orang, situasi, atau aktivitas tertentu dan bukan pada yang lain, atau minat sebagai akibat yaitu pengalaman efektif yang distimular oleh hadirnya seseorang atau sesuatu obyek, atau karena berpartisipasi dalam suatu aktifitas. Menurut Gie (2009), minat berarti sibuk, tertarik, atau terlihat sepenuhnya dengan sesuatu kegiatan karena menyadari pentingnya kegiatan itu.

Dari pengertian minat di atas memberikan pengertian bahwa minat menyebabkan perhatian di mana minat seolah-olah menonjolkan fungsi rasa dan perhatian seolah-olah menonjolkan fungsi pikiran. Hal ini menegaskan bahwa apa yang menarik minat menyebabkan pula kita berperhatian dan apa yang menyebabkan berperhatian kita tertarik, minat pun menyertainya jadi 
ada hubungan antara minat dan perhatian.

2. Pengertian Model Pembelajaran Course Review Horay

Model Pembelajaran Course

Review Horay merupakan model pembelajaran yang dapat menciptakan suasana kelas menjadi meriah dan menyenangkan karena setiap siswa yang dapat menjawab benar maka siswa tersebut diwajibkan berteriak 'hore!' atau yelyel lainnya yang disukai. Jadi, model pembelajaran course review horay ini merupakan suatu model pembelajaran yang dapat digunakan guru agar dapat tercipta suasana pembelajaran di dalam kelas yang lebih menyenangkan sehingga para siswa merasa lebih tertarik. Karena dalam model pembelajaran course review horay ini, apabila siswa dapat menjawab pertanyaan secara benar maka siswa tersebut diwajibkan meneriakan kata "hore" ataupun yelyel yang disukai dan telah disepakati oleh kelompok maupun individu siswa itu sendiri.

Model pembelajaran course review horay juga merupakan suatu model pembelajaran dengan pengujian pemahaman siswa menggunakan soal di mana jawaban soal dituliskan pada kartu atau kotak yang telah dilengkapi nomor dan untuk siswa atau kelompok yang mendapatkan jawaban atau tanda dari jawaban yang benar terlebih dahulu harus langsung berteriak "horay" atau menyanyikan yel-yel kelompoknya.

Agar pemahaman konsep materi yang akan dibahas dapat dikaji secara terarah maka seiring dengan perkembangan dunia pendidikan pembelajaran course review horay menjadi salah satu alternatif sebagai pembelajaran yang mengarah pada pemahaman konsep. Pembelajaran course review horay, merupakan salah satu pembelajaran kooperatif yaitu kegiatan belajar mengajar dengan cara pengelompokkan siswa ke dalam kelompok-kelompok kecil. Pembelajaran course review horay yang dilaksanakan merupakan suatu pembelajaran dalam rangka pengujian terhadap pemahaman konsep siswa menggunakan kotak yang diisi dengan soal dan diberi nomor untuk menuliskan jawabannya. Siswa yang paling terdahulu mendapatkan tanda benar langsung berteriak horay atau yel-yel lainnya. Melalui Pembelajaran course review horay diharapkan dapat melatih siswa dalam menyelesaikan masalah dengan pembentukkan kelompok kecil. Langkah-langkah model pembelajaran course review horay adalah sebagai berikut:

1) Guru menyampaikan kompetensi yang ingin dicapai.

2) Guru menyajikan atau mendemonstrasikan materi sesuai topik dengan tanya jawab

3) Guru membagi siswa dalam kelompok-kelompok.

4) Untuk menguji pemahaman siswa disuruh membuat kartu atau kotak sesuai dengan kebutuhan dan diisi dengan nomor yang ditentukan guru.

5) Guru membaca soal secara acak dan siswa menuliskan jawabannya di dalam kartu atau kotak yang nomornya disebutkan guru. 
6) Setelah pembacaan soal dan jawaban siswa telah ditulis didalam kartu atau kotak, guru dan siswa mendiskusikan soal yang telah diberikan tadi.

7) Bagi yang benar,siswa memberi tanda check list $(\sqrt{ })$ dan langsung berteriak horay atau menyanyikan yel-yelnya.

8) Nilai siswa dihitung dari jawaban yang benar dan yang banyak berteriak horay .

9) Guru memberikan reward pada yang memperoleh nilai tinggi atau yang banyak memperoleh horay.

10) Penutup

\section{Pengertian Pembelajaran Bahasa Indonesia}

Menurut Saud

dan

Rukmana (2006), belajar adalah suatu proses yang ditandai dengan adanya perubahan pada diri seseorang sebagai hasil dari pengalaman dan latihan. Sedangkan pembelajaran menurut Hamalik (2013), pembelajaran adalah upaya mengorganisasi lingkungan untuk menciptakan kondisi belajar bagi peserta didik. Secara umum bahasa adalah suatu bentuk ungkapan yang bentuk dasar ujaran atau suatu ungkapan dalam bentuk bunyi ujaran.Selain itu, bahasa juga dapat dimaknai sebagai alat komunikasi antar manusia (anggota masyarakat) berupa lambang bunyi ujaran yang dihasilkan oleh alat ucap manusia.

Maka dapat disimpulkan bahwa hakikat pembelajaran Bahasa Indonesia adalah sebuah upaya untuk mengarahkan peserta didik sehingga terampil berkomunikasi dalam Bahasa Indonesia, baik itu secara lisan maupun tulisan, serta baik dalam situasi formal maupun informal. Selain terampil berkomunikasi, peserta didik diharapkan memiliki sikap apresiatif terhadap karya sastra Bahasa Indonesia, para tokoh-tokoh kebahasaan,guru, dan sesama pelajar. Tujuan tentu saja, untuk menanamkan benih dan menumbuh kembangkan rasa nasionalisme terhadap bangsa dan negara Indonesia, yang pada akhirnya menjadikan NKRI yang bersatu, berdaulat, adil, dan makmur.

\section{B. METODE PENELITIAN}

Jenis penelitian ini adalah
penelitian tindakan kelas ini menggunakan bentuk kolaborasi, yang mana guru merupakan mitra kerja peneliti. Masing-masing memusatkan perhatiannya pada aspek-aspek penelitian tindakan kelas yang sesuai dengan keahliannya, guru sebagai praktisi pembelajaran, peneliti sebagai perancang dan pengamat yang kritis. Subjek dalam penelitian ini adalah siswa kelas VI SDS Methodist-2 Medan.

Menurut Kemnis \& Mc Taggart (dalam Arikunto, 2010), model penelitian tindakan kelas (PTK) menggambarkan adanya empat langkah dan pengulangannya, sebagai berikut :

1) Perencanaan (planning)

Adapun kegiatan yang dilakukan dalam kegiatan ini adalah melakukan tes awal yang bertujuan untuk mengetahui kemampuan awal siswa sebelum KBM dimulai dan mengidentifikasi permasalahn yang akan dianalisis berdasarkan tes awal.

2) Tindakan (action)

Kegiatan yang dilakukan dalam tahap ini adalah penyampaian materi 
pelajaran melibatkan aktivitas siswa secara individual maupun kelompok.

3) Pengamatan (observation)

Tahap pengamatan ini dilakukan di dalam kelas saat kegiatan pembelajaran berlangsung, di mana peneliti bertindak sebagai guru. Pengamatan yang dilengkapi dengan lembar pengamatan untuk menjaring data yang berkaitan dengan tindakan penelitian.

4) Refleksi (reflection)

Refleksi ini berfungsi untuk menganalisis dan memberikan makna terhadap data yang diperoleh, memperjelas data yang diperoleh dan mengambil simpulan dari tindakan yang telah dilakukan.Hasil refleksi ini kemudian digunakan sebagai dasar untuk tahap perencanaan selanjutnya.

Teknik pengumpulan data tentang kinerja guru pada penerapan model pembelajaran course review horay dilakukan dengan cara mengisi observasi kegiatan guru dan siswa yang dilakukan oleh pengamat lain. Selain peneliti pada saat proses pembelajaran pada setiap siklus untuk mengukur minat belajar siswa dan berupa tes instrumen hasil belajar.

\section{HASIL PENELITIAN}

\section{Siklus I}

Siklus I dilaksanakan sebanyak satu kali pertemuan berlangsung selama jam pelajaran yang terdiri dari 4 tahapan, yaitu sebagai berikut:

a. Tahap Perencanaan:

1) Mempersiapkan rencana pelaksanaan pembelajaran (RPP).

2) Membuat skenario pembelajaran .

3) Membuat lembar kerja siswa yang digunakan dalam kegiatan pembelajaran.

4) Mempersiapkan alat dan media pembelajaran yang diperlukan.

5) Mempersiapkan lembar pengamatan yang diperlukan.

b. Tahap Pelaksanaan:

i. Orientasi

1) Menampilkan suatu fenomena yang sering terjadi dalam kehidupan sehari-hari, yang berkaitan dengan topik yang dipelajari.

2) Mengaitkan topik yang akan dipelajari dengan fenomena lingkungan.

ii. Mengorganisasikan

1) Membagi siswa ke dalam kelompok kecil

2) Mengajak siswa untuk membentuk kelompok

iii. Membimbing

1) Memberikan masalah ke masing-masing kelompok

2) Memberi kesempatan kepada siswa untuk bertanya materi yang sedang dipelajari

3) Membimbing siswa dalam memecahkan masalah

4) Memberi kesempatan kepada siswa untuk memecahkan masalah

iv. Mengembangkan dan Menyajikan

1) Mengarahkan siswa untuk memecahkan masalah yang diberikan dengan mengembangkan hasil tugas.

2) Memberi kesempatan kepada siswa untuk menyajikan hasil tugas

v. Menganalisis dan Mengevaluasi

1) Memberi umpan balik untuk 
memperkuat dan memeriksa kembali hasil tugas yang telah diperoleh siswa

2) Memberi kesempatan kepada siswa untuk menyimpulkan hasil tugas.

vi. Tahap Pengamatan dan penilaian:

1) Hasil penilaian kinerja guru dalam pelaksanaan pembelajaran dapat dilihat dari hasil penilaian pada lembar penilaian yaitu jumlah skor 31 dengan persentase kinerja guru sebesar $65 \%$ dengan kategori baik

2) Hasil pengamatan aktivitas belajar siswa dalam pembelajaran dapat dilihat pada rekapitulasi hasil pengamatan lembar pengamatan, yaitu sebesar $62 \%$ dengan kategori cukup. Sedangkan untuk minat belajar siswa saat mengerjakan LKS sebesar $65 \%$, minat siswa pada saat pembahasan soal siklus I sebesar $74,4 \%$, minat siswa pada saat pembahasan materi pelajaran siklus I sebesar $80 \%$, minat siswa pada saat evaluasi siklus I sebesar $80,4 \%$.

Hasil observasi pada
siklus I ini menjadi acuan
perbaikan pada siklus
berikutnya.Tahap refleksi
yang di lakukan mengacu
pada siklus I di mana tujuan
yang diharapkan belum
tercapai.Segala kelemahan-
kelemahan dan kekurangan,
baik dari sisi guru dan siswa
harus diperbaiki dan
ditingkatkan.

Beberapa siswa telah menunjukkan bahwa telah ada peningkatan hasil belajar dari hasil evaluasi belajar tersebut nilai rata-rata 75 maka dapat disimpulkan bahwa melalui model pembelajaran course review horay dapat dijadikan sebagai upaya menumbuhkan minat belajar siswa pada pelajaran Bahasa Indonesia kelas VI SDS Methodist-2 Medan.

d. Tahap Refleksi:

1) Kinerja guru dalam proses pembelajaran:

Hasil penilaian pada kinerja guru melalui model pembelajaran Course Review Horay adalah sebagai berikut: (a) jumlah skor kinerja guru 31, (b) persentase kinerja guru $65 \%$,

(c) kategori kinerja guru baik.

2) Aktivitas belajar siswa: Dari hasil penilaian pada aktivitas belajar siswa pada siklus I terdapat 21 siswa atau $62 \%$ siswa aktif mengikuti pembelajaran pendidikan Bahasa Indonesia.Dengan demikian penelitian pada siklus I belum memenuhi indikator keberhasilan, sehingga penelitian ini perlu dilanjutkan pada siklus berikutnya.

\section{Siklus II}

Siklus II dilaksanakan sebanyak satu kali pertemuan berlangsung selama jam pelajaran yang terdiri dari 4 
tahapan, yaitu sebagai berikut:

a. Tahap Perencanaan:

1) Mempersiapkan

rencana pelaksanaan pembelajaran (RPP).

2) Membuat skenario pembelajaran

3) Membuat lembar kerja siswa yang digunakan dalam kegiatan pembelajaran.

4) Mempersiapkan alat dan media pembelajaran yang diperlukan.

5) Mempersiapkan lembar pengamatan yang diperlukan.

b. Tahap Pelaksanaan:

i. Orientasi

1) Menampilkan suatu fenomena yang sering terjadi dalam kehidupan sehari-hari, yang berkaitan dengan topik yang dipelajari.

2) Mengaitkan topik yang akan dipelajari dengan fenomena lingkungan.

ii. Mengorganisasikan

1) Membagi siswa ke dalam kelompok kecil

iii. Membimbing

1) Memberikan masalah ke masing-masing kelompok

2) Memberi kesempatan kepada siswa untuk bertanya materi yang sedang dipelajari

3) Membimbing siswa dalam memecahkan masalah

iv. Mengembangkan dan Menyajikan

1) Mengarahkan siswa untuk memecahkan masalah yang diberikan dengan mengembangkan hasil tugas.

2) Memberi kesempatan kepada siswa untuk menyajikan hasil tugas

v. Menganalisis dan Mengevaluasi
1) Memberi umpan balik untuk memperkuat dan memeriksa kembali hasil tugas yang telah diperoleh siswa

2) Memberi kesempatan kepada siswa untuk menyimpulkan hasil tugas.

c. Tahap Pengamatan dan penilaian:

Dari hasil pengamatan persentase kinerja guru dalam menerapkan model course review horay adalah sebesar $85 \%$ dengan kategori sangat baik. Dan persentase siswa aktif dalam belajar sebesar 88\% dengan kategori sangat baik. Untuk minta minat siswa saat mengerjakan LKS pada siklus II sebesar $88,4 \%$, minat siswa pada saat pembahasan soal siklus II sebesar $86,8 \%$, minat siswa pada saat pembahasan materi pelajaran siklus II sebesar $88 \%$, minat siswa pada saat evaluasi siklus II sebesar 90,4\%. Untuk evaluasi belajar tersebut nilai rata-rata 86.56 maka dapat disimpulkan bahwa melalui model pembelajaran course review horay dapat dijadikan sebagai upaya menumbuhkan minat belajar siswa pada pelajaran Bahasa Indonesia kelas VI SDS Methodist-2 Medan TP. 2019/2020. Walau pada siklus II ini menunjukkan hasil yang baik tetapi beberapa penyempurnaan masih perlu dilakukan antara lain :

1) Tata tertib belajar perlu ditingkatkan seperti perlu adanya pelaksanaan pembatasan waktu, ketelitian siswa, dan kelengkapan jawaban.

2) Pada saat pembahasan soal guru sebaiknya menuliskan soal yang akan diisi oleh siswa secara berurutan di papan tulis kemudian menunjuk siswa untuk mengisi. 
3) Pada saat pemberian tugas tempat duduk siswa sebaiknya berjauhan dengan siswa yang lain agar tidak saling meniru jawaban.

d. Tahap Refleksi:

1) Kinerja guru dalam proses pembelajaran:

Hasil penilaian pada kinerja guru melalui model pembelajaran Course Review Horay adalah sebagai berikut:

(a) jumlah skor kinerja guru 41,

(b) persentase kinerja guru $85 \%$,

(c) kategori kinerja guru Sangat baik.

2) Aktivitas belajar siswa:

Dari hasil penilaian pada aktivitas belajar siswa pada siklus II terdapat 30 siswa atau $88 \%$ siswa aktif mengikuti pembelajaran pendidikan Bahasa Indonesia. Dengan demikian penelitian pada siklus II sudah memenuhi indikator keberhasilan, sehingga penelitian ini tidak perlu dilanjutkan pada siklus berikutnya.

\section{KESIMPULAN DAN SARAN}

a. Simpulan

Berdasarkan penulisan dan pembahasan, maka dapat disimpulkan sebagai berikut :

a. Hasil persentase kinerja guru pada siklus I yaitu sebesar $65 \%$ dengan kategori cukup. Sedangkan untuk minat belajar siswa saat mengerjakan LKS sebesar 65\%, minat siswa pada saat pembahasan soal sebesar $74,4 \%$, minat siswa pada saat pembahasan materi pelajaran sebesar $80 \%$, minat siswa pada saat evaluasi sebesar $80,4 \%$.

b. Hasil persentase kinerja guru pada siklus II adalah sebesar $85 \%$ dengan kategori sangat baik. Dan persentase siswa aktif dalam belajar sebesar $88 \%$ dengan kategori sangat baik. Untuk minta minat siswa saat mengerjakan LKS sebesar $88,4 \%$, minat siswa pada saat pembahasan soal sebesar $86,8 \%$, minat siswa pada saat pembahasan materi pelajaran sebesar $88 \%$, minat siswa pada saat evaluasi sebesar $90,4 \%$. Untuk evaluasi belajar tersebut nilai rata-rata 86.56

c. Berdasarkan hasil penelitian disimpulkan bahwa melalui model pembelajaran course review horay dapat dijadikan sebagai upaya menumbuhkan minat belajar siswa pada pelajaran Bahasa Indonesia kelas SDS Methodist-2 Medan TP. 2019/2020.

b. Saran

Berdasarkan hasil penelitian ini maka saran yang dapat peneliti berikan adalah:

a. Agar pengetahuan pendidikan kewarganegaraan siswa meningkat, siswa harus memiliki kreativitas yang tinggi dalam proses pembelajaran.

b. Agar hasil belajar siswa bisa meningkat secara optimal, hendaknya guru menumbuhkan kreativitas siswa dengan perbaikan penyempurnaan proses pembelajaran agar minat belajar siswa meningkat.

\section{DAFTAR PUSTAKA}

Arikunto, S. 2010. Prosedur Penelitian Suatu Pendekatan Praktik. Jakarta: Rineka Cipta. Cahyono 
Dakir. 2004. Perencanaan dan Pengembagan Kurikulum. Jakarta: Rineka Cipta

Dimyati Mahmud. (2001). Psikologi Suatu Pengantar.Yogyakarta : BPFE

Gie, The Liang. 2009. Administrasi Perkantoran Modern. Yogyakarta : Liberty

Hamalik, Oemar. 2013. Proses Belajar Mengajar.Jakarta : PT.Bumi Aksara

Saud dan Rukmana.2006. Pengelolaan Kelas dan Berbagai Faktor Yang Mempengaruhi. Jakarta: remaja. AECT. 